Short Communication

\title{
Transferability and characterization of microsatellite markers in two Neotropical Ficus species
}

\author{
Alison Gonçalves Nazareno ${ }^{1}$, Rodrigo Augusto Santinelo Pereira ${ }^{2}$, Juliana Massimino Feres ${ }^{3}$, Moacyr \\ Antônio Mestriner ${ }^{3}$ and Ana Lilia Alzate-Marin ${ }^{3}$ \\ ${ }^{1}$ Programa de Pós-graduação em Biologia Comparada, Faculdade de Filosofia, Ciências e Letras \\ de Ribeirão Preto, Universidade de São Paulo, Ribeirão Preto, SP, Brazil. \\ ${ }^{2}$ Departamento de Biologia, Faculdade de Filosofia, Ciências e Letras de Ribeirão Preto, \\ Universidade de São Paulo, Ribeirão Preto, SP, Brazil. \\ ${ }^{3}$ Laboratório de Genética Vegetal, Departamento de Genética, Faculdade de Medicina de Ribeirão Preto, \\ Universidade de São Paulo, Ribeirão Preto, SP, Brazil.
}

\begin{abstract}
Microsatellite markers were transferred and characterized for two Neotropical fig tree species, Ficus citrifolia and Ficus eximia. Our study demonstrated that microsatellite markers developed from different subgenera of Ficus can be transferred to related species. In the present case, 12 of the 15 primer pairs tested ( $80 \%)$ were successfully transferred to both of the above species. Eleven loci were polymorphic when tested across $60 \mathrm{~F}$. citrifolia and $60 \mathrm{~F}$. eximia individuals. For $F$. citrifolia, there were 4 to 15 alleles per locus, whereas expected heterozygosities ranged from 0.31 to 0.91 . In the case of $F$. eximia, this was 2 to 12 alleles per locus and expected heterozygosities from 0.42 to 0.87 .
\end{abstract}

Key words: ecological genetics, Ficus citrifolia, Ficus eximia, Moraceae, SSRs.

Received: December 3, 2008; Accepted: March 23, 2009.

Effective strategies for the conservation of genetic resources in tropical forests are of great importance, mainly due to the negative impacts arising from the reduction in biological diversity. This is especially true with regard to ecologically important species such as fig trees (Ficus species, family Moraceae), which are considered to be keystone- resources in tropical forests, through supplying frugivores with fruit during periods of food-scarcity (Shanahan et al., 2001). Furthermore, plants of the genus Ficus are considered as a classic example of plant-insect mutualism (Weiblen, 2002). With few exceptions, each of the 750 Ficus species maintains an obligatory symbiotic interaction with a specific pollinating wasp species (Hymenoptera: Agaonidae). However, little is known about the genetic diversity and population structure of Ficus species (Dick et al., 2008). Microsatellite markers (simple sequence repeats - SSR) are informative tools used to assess the genetic structure of populations as well as basic quantitative genetic parameters. Although microsatellite markers constitute informative systems for ecological genetics, they have

Send correspondence to Ana Lilia Alzate-Marin. Laboratório de Genética Vegetal, Departamento de Genética, Faculdade de Medicina, Universidade de São Paulo, Av. Bandeirantes 3900, 14049-900 Ribeirão Preto, SP, Brazil. E-mail: anaalzate@ rge.fmrp.usp.br. only been isolated for seven of the 750 species of Ficus (Khadari et al., 2001; Giraldo et al., 2005; Zavodna et al., 2005; Vignes et al., 2006; Ahmed et al., 2007; Bandelj et al., 2007; Crozier et al., 2007). Nevertheless, the high transferability of these markers has allowed for cross amplification in 47 Ficus species (Khadari et al., 2001; Giraldo et al., 2005; Vignes et al., 2006). Moreover, indications of high transferability within a particular genus has also come to light from other areas of research (Poncet et al., 2004; Moon et al., 2008). Given the time consuming and relatively costly process of isolating microsatellites and the low frequency of SSRs in plants (Powell et al., 1996), it is a decided advantage to be able to utilize primer sequences identified in one species in other closely related ones. Here, we examine the transferability and the characterization of microsatellite markers previously developed from different subgenera of Ficus for two species occurring in Brazil, Ficus citrifolia P. Miller and Ficus eximia Schott.

The subgenus Urostigma section Americana, to which $F$. citrifolia and $F$. eximia belong, includes monoecious plants that may occur as trees of hemi-epiphyte growth form (Berg, 1989). Ficus citrifolia normally grows as a hemiepiphyte on other trees or buildings and frequently develops within disturbed areas. Ficus eximia usually germinates on fallen trunks and grows as a free-standing tree in 
humid patches in the forest. During January and February, 2008, we sampled 120 individuals from two natural populations (30 individuals per area per species), $350 \mathrm{~km}$ apart, located at the Parque Estadual Morro do Diabo (22 $27^{\prime}-22^{\circ}$ $\left.40^{\prime} \mathrm{S}, 52^{\circ} 10^{\prime}-52^{\circ} 22^{\prime} \mathrm{W}\right)$ and at the Estação Ecológica de Caetetus (22 $\left.41^{\prime}-22^{\circ} 46^{\prime} \mathrm{S}, 49^{\circ} 10^{\prime}-49^{\circ} 16^{\prime} \mathrm{W}\right)$, both in southeastern Brazil.

DNA for microsatellite analysis was extracted from frozen leaves by using the cetyltrimethyl ammonium bromide (CTAB) extraction method (Doyle and Doyle, 1990). Fifteen microsatellite loci, previously developed for Ficus (Pharmacosycea) insipida (Vignes et al., 2006), Ficus (Sycomorus) racemosa and Ficus (Urostigma) rubiginosa (Crozier et al., 2007), were tested for cross amplification in specimens of $F$. citrifolia and $F$. eximia. Using polymerase chain reaction (PCR), a screening of each primer pair through ten annealing temperatures (between $46-55{ }^{\circ} \mathrm{C}$ ) was accomplished with 10 individuals of $F$. citrifolia and $F$. eximia. Microsatellite loci were amplified in a final volume of $10 \mu \mathrm{L}$ containing $0.3 \mu \mathrm{M}$ of each primer, $1 \mathrm{U}$ Taq DNA polymerase, $0.25 \mathrm{mM}$ of each dNTP, $1 \times \mathrm{MgCl}_{2}$-free reaction buffer $[75 \mathrm{mM}$ Tris- $\mathrm{HCl} \mathrm{pH} 9.0,50 \mathrm{mM} \mathrm{KCl}$ and $\left.20 \mathrm{mM}\left(\mathrm{NH}_{4}\right)_{2} \mathrm{SO}_{4}\right], 1.5 \mathrm{mM} \mathrm{MgCl}_{2}$ and $2.5 \mathrm{ng}$ of template DNA. The amplification was performed using a MasterCycler Eppendorf under the following conditions: $5 \mathrm{~min}$ of denaturation at $96^{\circ} \mathrm{C}$ and 30 cycles of $30 \mathrm{~s}$ of initial denaturation at $94{ }^{\circ} \mathrm{C}, 1 \mathrm{~min}$ of annealing at $T_{\mathrm{a}}$ (Table 1) and $1 \mathrm{~min}$ of extension at $72{ }^{\circ} \mathrm{C}$, to finish with $7 \mathrm{~min}$ of elongation at $72{ }^{\circ} \mathrm{C}$. Amplified fragments were separated on $10 \%$ denaturing polyacrylamide gels in $8 \mathrm{M}$ urea and $1 \mathrm{x}$ TBE buffer, to then be stained with silver nitrate (Sanguinetti et al., 1994). The quantification of allele size was scored against a 10 bp DNA ladder standard (Invitrogen).

Genetic diversity parameters and probabilities of paternity exclusion were estimated using CERVUS version 3.0 (Kalinowski et al., 2007). The FSTAT software package version 1.2 (Goudet, 2001) was used to test all loci for linkage disequilibrium, with application of Bonferroni correction for multiple comparisons.

Our study demonstrated that microsatellite markers developed from different subgenera of Ficus can be transferred to related species. We successfully transferred 12 of the 15 primer pairs tested (80\%) to both of the species, $F$. citrifolia and $F$. eximia (Table 1). Similar allele numbers and length of amplification products were apparent in most of the successful loci, when compared with the species from which they were developed (Table 1). Of the 12 loci transferred, 11 were polymorphic for both $F$. citrifolia and F. eximia. Loci FinsT7 and Frub154 were monomorphic in only one species. Eighty-seven F. citrifolia and $77 \mathrm{~F}$. eximia allelic variants were identified (Table 1). Furthermore, the average for heterozygosity and the mean number of alleles per loci were, respectively, 0.67 and 7.3 in $F$. citrifolia and 0.69 and 6.4 in F. eximia. Heterozygosity val- ues of $F$. citrifolia and $F$. eximia in this study were within those for Ficus species reported in previous studies (Bandelj et al., 2007; Crozier et al., 2007). The level of heterozygosity found in a population is highly dependent on the mating system and the evolutionary history of the species, besides a range of other factors. Although various microsatellite markers and sample sizes have been used in diversity studies on Ficus species, these same values made it possible for us to assume the present status of genetic variability due to the mating system and plant-insect mutualism. Pollen and diaspores in Ficus species are dispersed over long distances (Kinnaird et al., 1996; Nason et al., 1996), thereby implying that the flight distance of pollinators and dispersal range might predict high levels of genetic variation in these species (Hamrick and Loveless, 1989; Epperson and Alvarez-Buylla, 1997; Nazareno and Carvalho, 2008).

There were significant deviations from HardyWeinberg equilibrium (HWE) in seven $F$. citrifolia loci. As to $F$. eximia, nine loci were not in HWE (Table 1). Either the intrapopulation substructure produced by the sampling effect or the presence of null alleles may have caused these deviations, since analyses at the population level showed deviations from HWE for these same loci. Furthermore, as these results were obtained by using microsatellites developed in another species, the probability of a null allele occurring would be much higher than in the case of testing in the species from which they were isolated (Kim et al., 2004). In future studies, the influence of null alleles on the transferability of microsatellite markers and their applicability in other species should be investigated.

The chi-square test for the independent segregation hypothesis indicated that all loci for $F$. citrifolia were in linkage equilibrium. As to $F$. eximia, however, significant linkage disequilibrium was found for the loci Frub38 and Frub415. The combined values for probabilities of paternity exclusion in all the 11 polymorphic loci were 0.996 for $F$. citrifolia and 0.995 for $F$. eximia. Using the 11 polymorphic loci enabled us to distinguish all the $60 \mathrm{~F}$. citrifolia and $60 F$. eximia individuals in two populations from southeastern Brazil. Hence, transferred microsatellite markers should allow for detailed parentage studies in natural populations, even in situations where both maternity and paternity are unknown. Moreover, these microsatellite loci could be highly useful for providing data on population genetics.

The high transferability of microsatellite markers developed from different subgenera of Ficus for F. citrifolia and $F$. eximia confirm the general applicability of Ficus microsatellite primers to this very large genus. Currently, we are using these markers to investigate the impact of tropical deforestation on population structure and genetic diversity in forest fragments in the Atlantic Rain Forest sensu lato, where $F$. citrifolia and $F$. eximia are native. 


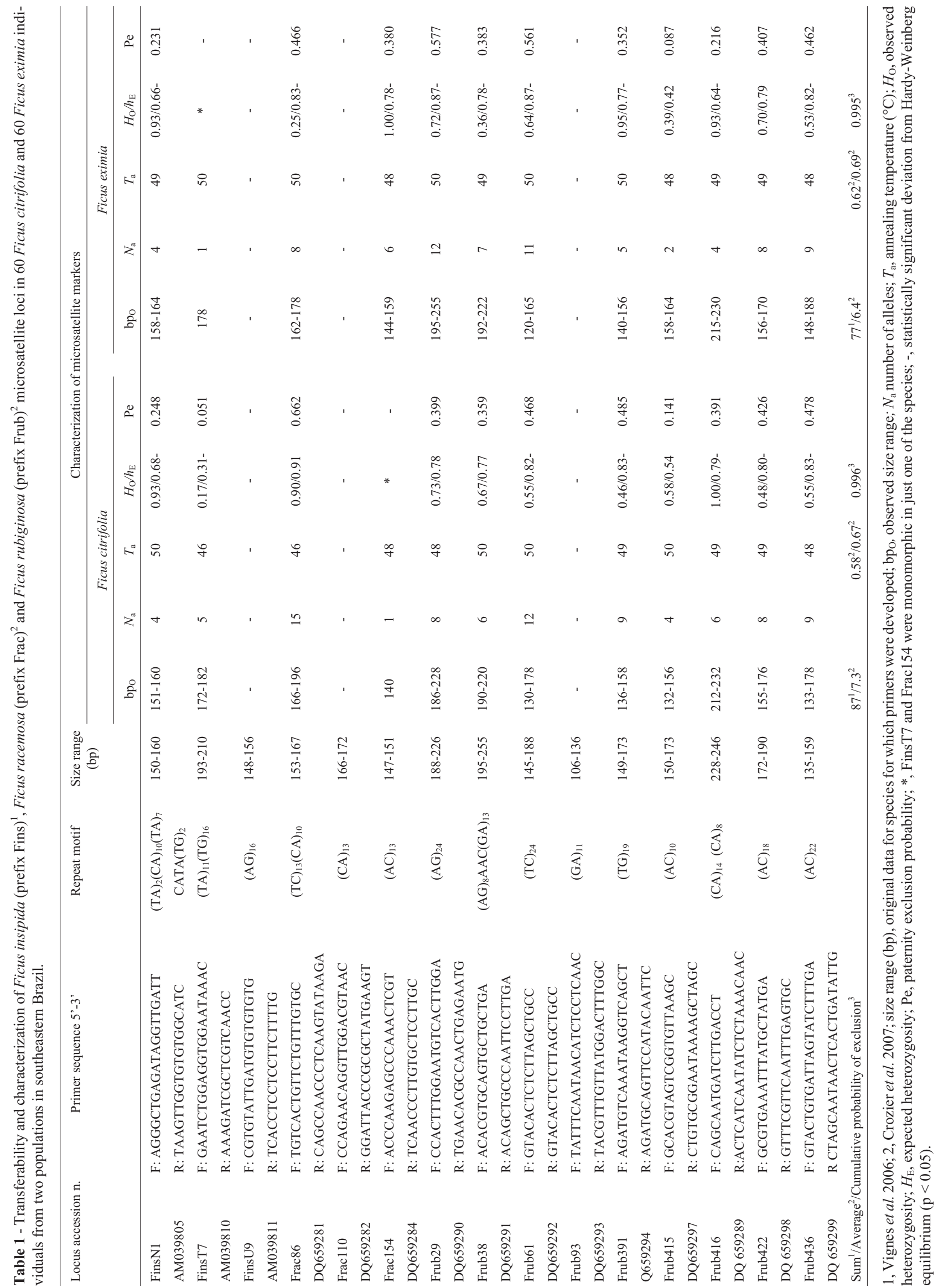




\section{Acknowledgments}

We thank the Instituto Florestal for permitting this research (ref. \# 43.487/2007) and for the use of the facilities in protected areas. This study was supported by grants from FAPESP (R.A.S.P \#04/10299-4, A.L.A.M. \#03/041994/2004) the Provost for Research of Sao Paulo University (A.L.A.M.) and FAEPA (M.A.M.). A.G.N. was supported by a fellowship from CAPES and J.M.F. from FAPESP (\#2006/05152-0). The authors thank Marcela Corbo Guidugli for technical support on microsatellite analyses and the anonymous referees for their useful comments on a previous version of the manuscript.

\section{References}

Ahmed S, Dawson DA, Compton SG and Gilmartin PM (2007) Characterization of microsatellite loci in the African fig Ficus sycomorus L. (Moraceae). Mol Ecol Notes 7:11751177.

Bandelj D, Javornik B and Jakse J (2007) Development of microsatellite markers in the common fig, Ficus carica L. Mol Ecol Notes 7:1311-1314.

Berg CC (1989) Classification and distribution of Ficus. Experientia 45:605-611.

Crozier YC, Jia XC, Yao JY, Field AR and Cook JM (2007) Microsatellite primers for Ficus racemosa and Ficus rubiginosa. Mol Ecol Notes 7:57-59.

Dick CW, Hardy OJ, Jones FA and Petit RJ (2008) Spatial scales of pollen and seed-mediated gene flow in tropical rain forest trees. Trop Plant Biol 1:20-33.

Doyle JJ and Doyle JL (1990) Isolation of plant DNA from fresh tissue. Focus 12:13-15.

Epperson BK and Alvarez-Buylla ER (1997) Limited seed dispersal and genetic structure in life stages of Cecropia obtusifolia. Evolution 51:275-282.

Giraldo E, Viruel MA, López-Corrales M and Hormaza JI (2005) Characterization and cross-species transferability of microsatellites in the common fig (Ficus carica L.). J Hortic Sci Biotechnol 80:217-224.

Goudet J (2001) FSTAT, v. 1.2: A computer program to calculate F-statistics. Heredity 86:485-486.

Hamrick JL and Loveless MD (1989) The genetic structure of tropical tree populations: Associations with reproductive biology. In: Bock JL and Linhart YB (eds) The Evolutionary Ecology of Plants. Westview Press, Boulder, pp 129-146.

Kalinowski ST, Taper ML and Marshall TC (2007) Revising how the computer program CERVUS accommodates genotyping error increases success in paternity assignment. Mol Ecol 16:1099-1106.

Khadari B, Hochu I, Santoni S and Kjellberg F (2001) Identification and characterization of microsatellite loci in the common fig (Ficus carica L.) and representative species of the genus Ficus. Mol Ecol Notes 1:191-193.

Kim K-S, Min M-S, An J-H and Lee H (2004) Cross-species amplification of Bovidae microsatellites and low diversity of the endangered Korean Goral. J Hered 95:521-525.

Kinnaird MF, O'Brien TG and Suryadi S (1996) Population fluctuation in Sulawesi Red-Knobbed Hornbills: Tracking figs in space and time. The Auk 113:431-440.

Moon HS, Nicholson JS and Lewis RS (2008) Use of transferable Nicotiana tabacum L. microsatellite markers for investigating genetic diversity in the genus Nicotiana. Genome 51:547-599.

Nason JD, Herre EA and Hamrick JL (1996) Paternity analysis of the breeding structure of strangler fig populations: Evidence for substantial long-distance wasp dispersal. J Biogeogr 23:501-512.

Nazareno AG and Carvalho D (2008) What the reasons for no inbreeding and high genetic diversity of the neotropical fig tree Ficus arpazusa? Conserv Genet (DOI 10.1007/s10592-008-9776-x).

Poncet V, Hamon P, Minier J, Carasco C, Hamon S and Noirot M (2004) SSR cross-amplification and variation within coffe trees (Coffea spp.). Genome 47:1071-1081.

Powell W, Machray GC and Provan J (1996) Polymorphism revealed by simple sequence repeats. Trends Plant Sci 1:215222.

Sanguinetti CJ, Dias EN and Simpson AJG (1994) Rapid silver staining and recovery of PCR products separated on polyacrylamide gels. Biotechnology 17:914-921.

Shanahan M, Compton SG, So S and Corlett R (2001) Fig-eating by vertebrate frugivores: A global review. Biol Rev 76:529572.

Vignes H, Hossaert-McKey M, Beaune D, Fevre D, Anstett MC, Borges RM, Kjellberg F and Chevallier MH (2006) Development and characterization of microsatellite markers for a monoecious Ficus species, Ficus insipida, and cross-species amplification among different sections of Ficus. Mol Ecol Notes 6:792-795.

Weiblen GD (2002) How to be a fig wasp. Annu Rev Entomol 47:299-330.

Zavodna M, Arens P, Van Dijk PJ and Vosman B (2005) Development and characterization of microsatellite markers for two dioecious Ficus species. Mol Ecol Notes 5:355-357.

\section{Associate Editor: Márcio de Castro Silva Filho}

License information: This is an open-access article distributed under the terms of the Creative Commons Attribution License, which permits unrestricted use, distribution, and reproduction in any medium, provided the original work is properly cited. 